\title{
Pengaruh Rasio lancar, Debt to Total Asset, Return on Investment terhadap Dividen Payout Ratio di Perusahaan Consumer Goods yang Terdaftar di Bursa Efek Indonesia Periode 2011-2017
}

\author{
Wenny Anggeresia Ginting \\ Universitas Prima Indonesia \\ gintinganggresiawenny@gmail.com
}

\author{
Karina Anatasia Asmara Silitonga \\ Universitas Prima Indonesia \\ nyidiananggara@gmail.com
}

\author{
Mariani \\ Universitas Prima Indonesia \\ marianichen9@gmail.com
}

\begin{abstract}
ABSTRAK
Tujuan penelitian adalah menguji dan menganalisis pengaruh rasio lancar, debt to total aset, return on investment terhadap dividen payout ratio di Perusahaan Consumer Goods yang terdaftar di Bursa Efek Indonesia Periode 2011-2017. Penelitian ini menggunakan pendekatan penelitian kuantitatif. Jenis penelitian pada penelitian eksplanatori. Sifat penelitian ini adalah bersifat hubungan kausal. Populasi yang digunakan dalam penelitian ini adalah semua Perusahaan Consumer Goods yang terdaftar di Bursa Efek Indonesia periode 2011-2017 sebanyak 37 perusahaan. Sampel penelitian sebanyak 6 Perusahaan Consumer Goods yang terdaftar di Bursa Efek Indonesia periode 2011-2017. Metode regresi berganda yang digunakan dalam penelitian ini. Hasil penelitian ini adalah rasio lancar berpengaruh dan signifikan terhadap dividen payout ratio di Perusahaan Consumer Goods yang terdaftar di Bursa Efek Indonesia Periode 2011-2017. Debt to total aset berpengaruh dan signifikan terhadap dividen payout ratio di Perusahaan Consumer Goods yang terdaftar di Bursa Efek Indonesia Periode 2011-2017. Return on investment berpengaruh dan signifikan terhadap dividen payout ratio di Perusahaan Consumer Goods yang terdaftar di Bursa Efek Indonesia Periode 2011-2017. Rasio lancar, debt to total aset, return on investment berpengaruh dan signifikan terhadap dividen payout ratio di Perusahaan Consumer Goods yang terdaftar di Bursa Efek Indonesia Periode 2011-2017.
\end{abstract}

Kata Kunci : Rasio lancar, debt to total aset, return on investment dan dividen payout ratio

\section{PENDAHULUAN}

Industri barang konsumsi (Consumer Goods) merupakan sektor industri dengan perusahaan yang bergerak pada industri barang untuk konsumsi seperti makanan, minuman, obat-obatan, kosmetik, rokok dan peralatan rumah tangga.
Pertumbuhan permintaan terhadap barang konsumsi relatif stabil seiring penyesuaian daya beli konsumen. Data dari Badan Pusat Statistik menunjukkan rata-rata $51 \%$ pengeluaran per bulan masyarakat Indonesia ditujukan untuk konsumsi makanan, dengan makanan jadi mengambil porsi paling besar, sekitar 11\%-12\% 
terhadap total pengeluaran. Hal ini yang menjadikan industri pengolahan makanan dan minuman Indonesia menarik.

Investor menanamkan modalnya akan mempertimbangkan dengan sebaikbaiknya ke perusahaan mana modal ditanamkan. Untuk itulah para investor memerlukan laporan keuangan perusahaan di mana mereka menanamkan modalnya guna melihat prospek keuntungan di masa mendatang dan perkembangan perusahaan selanjutnya, untuk mengetahui kondisi kerja atau kondisi keuangan jangka pendek perusahaan tersebut. Pada umumnya tujuan utama investor dalam menanamkan dananya di perusahaan untuk mencari pendapatan atau tingkat pengembalian investasi (return), yang salah satunya berupa pendapatan dividen. Dalam kondisi demikian, setiap perusahaan dituntut untuk dapat beroperasi dengan tingkat efisiensi yang cukup tinggi supaya tetap mempunyai keunggulan dan daya saing dalam upaya menghasilkan laba bersih seoptimal mungkin.

Dividen payout ratio secara umum sebagai pembayaran laba perusahaan kepada pemegang sahamnya. Dividen payout ratio ini berpengaruh pada sikap atau reaksi para investor yang berarti pemotongan dividen dapat dipandang negatif oleh para investor, karena pemotongan seperti itu seringkali dikaitkan dengan kesulitan keuangan yang dihadapi perusahaan. Dalam menentukan dividen payout ratio perlu memperhatikan beberapa faktor, diantaranya : Rasio Lancar, Debt to Total Aset, Return on Investment.

Rasio lancar mengukur kemampuan perusahaan dalam melunasi kewajiban jangka pendek yang segera jatuh tempo. Posisi rasio lancar berpengaruh pada kemampuan perusahaan membayar dividen, karena dividen dibayarkan dan tidak dengan laba ditahan, sehingga perusahaan harus memiliki kas tersedia untuk melakukan pembayaran dividen maupun kewajiban lancar yang segera jauh tempo. Perusahaan dengan ketersediaan kas yang lebih tinggi memungkinkan untuk membayar dividen perusahaan dari perusahaan dengan ketersediaan kas yang cukup.

Debt to Total Aset dapat mempengaruhi perusahaan dalam melakukan pembagian dividen. Semakin meningkatnya rasio hutang maka hal tersebut berdampak terhadap dividen payout ratio yang dibagikan perusahaan menjadi rendah. Dengan biaya bunga yang semakin besar maka profiabilitas (earning after tax) semakin berkurang (karena sebagian digunakan untuk membayar bunga), maka hak para pemegang saham (dividen) juga semakin berkurang (menurun). Jika beban utang semakin tinggi, maka kemampuan perusahaan untuk membagi dividen akan semakin rendah.

Perusahaan besar mempunyai Return on Investment tinggi akan lebih mudah memasuki pasar modal atau memperoleh dana dari luar untuk pembiayaannya. Perusahaan yang sudah mantap akan mempunyai tingkat dividen yang lebih tinggi dibanding dengan perusahaan kecil atau masih baru.

\section{LANDASAN TEORI}

\subsection{Pengaruh Rasio Lancar Terhadap Dividen Payout Ratio}

Menurut Rodoni dan Ali (2014:117)

posisi likuiditas menunjukkan laba ditahan yang telah diinvestasikan dalam bentuk aktiva tetap dapat menunjukkan posisi likuiditas perusahaan rendah dan terdapat kemungkinan perusahaan tidak mampu lagi membayarkan dividennya.

$$
\text { Menurut Gumanti }
$$
perusahaan memerlukan likuiditas tinggi, dalam hal ini dapat berbentuk sumber pendanaan internal yang berupa laba 
ditahan, maka dividen yang akan dibagikan seharusnya dikurangi karena membayar dividen berarti pengeluaran kas dan pengeluaran kas berarti pengurangan kemampuan likuiditas (memenuhi kewajiban lancarnya). Apalagi jika kebutuhan dana tersebut sangat mendesak yang memaksa manajemen untuk mengurangi atau bahkan menunda pembayaran dividen kepada pemegang saham. Artinya, kebutuhan akan likuiditas lebih menentukan besar kecilnya dividen jika dibandingkan dengan posisi laba ditahan.

Menurut Hery (2013:30) dividen merupakan suatu kegiatan yang bersifat cash outflow, sehingga semakin tinggi tingkat likuiditas perusahaan maka akan semakin mampu perusahaan dalam membayar dividen.

\subsection{Pengaruh Debt to Asset Ratio Terhadap Dividen Payout Ratio}

Menurut Hery (2013:37) semakin besar proporsi utang yang digunakan dalam struktur modal, maka akan semakin besar pula jumlah kewajiban perusahaan kepada kreditor (baik utang pokok maupun utang bunga). Peningkatan saldo utang pada gilirannya akan mempengaruhi besar kecilnya laba yang tersedia bagi para pemegang saham, termasuk dividen yang akan diterima, karena pembayaran kewajiban kepada kreditor akan menjadi lebih diprioritaskan dari pada pembayaran dividen. Jika beban utang semakin tinggi, maka kemampuan perusahaan untuk membagi dividen akan semakin rendah.

Menurut Gumanti (2013:83) jika perusahaan memiliki kewajiban (utang) yang besar dan harus segera dibayar, maka sangat mungkin bahwa pemegang saham harus dikorbankan, yaitu menunda atau mengurangi pembayaran dividen. Kebutuhan dana untuk pemenuhan investasi memang tidak selamanya dapat dipenuhi dari sumber dana internal.

Menurut Nidar (2016:264) pada umumnya perjanjian hutang antara perusahaan dengan membatasi pembayaran dividen. Misalnya, dividen hanya dapat diberikan jika kewajiban hutang telah dipenuhi perusahaan dan atau rasio-rasio keuangan menunjukkan perusahaan dalam kondisi sehat.

\subsection{Pengaruh Return On Invesment Terhadap Dividen Payout Ratio \\ Menurut Sjahrial (2008:306)} besarnya dividen yang dibagikan akan tergantung pada laba yang diperoleh preusahaan. Peruahaan hanya bisa meningkatkan pembagian dividen kalau laba meningkat. Maksimum jumlah dividen yang dibagikan akan sama dengan laba yang diperoleh.

Menurut Rodoni dan Ali (2014:117) kemampuan memasuki pasar modal. Perusahaan besar yang sudah mempunyai profitabilitas yang tinggi dan keuntungan yang stabil akan lebih mudah memasuki pasar modal atau memperoleh dana dari luar untuk pembiayaannya. Karena itu perusahaan yang sudah mantap akan mempunyai tingkat dividen yang lebih tinggi dibanding dengan perusahaan kecil atau masih baru.

Menurut Gumanti (2013:86) laba yang stabil dari waktu ke waktu sangat menentukan besar kecilnya dividen yang akan dibagikan kepada pemegang saham. Kestabilan berarti kemampuan menjaga laba pada level yang ditetapkan sesuai dengan keinginan.

\section{METODE PENELITIAN}

\subsection{Pendekatan Penelitian}

Penelitian ini menggunakan pendekatan penelitian kuantitatif. Menurut 
Sugiyono (2012:13), penelitian kuantitatif dapat diartikan sebagai metode penelitian yang digunakan untuk meneliti pada populasi atau sampel tertentu, teknik pengambilan sampel pada umumnya dilakukan secara random, pengumpulan data menggunakan instrumen penelitian, analisis data bersifat kuantitatif/statistik dengan tujuan untuk menguji hipotesis yang telah ditetapkan.

\subsection{Jenis Penelitian}

Jenis penelitian pada penelitian eksplanatori. Menurut Soewadji (2012:34), penelitian eksplanatori bertujuan tidak hanya menjelaskan suatu gejala atau fenomena melainkan juga memberikan penjelasan bagaimana hubungan antara variabel-variabel yang diteliti, sehingga dilihat dari tujuannya, penelitian eksplanatori dapat disamakan dengan penelitian deskriptif analitik.

\subsection{Sifat Penelitian}

Sifat penelitian ini adalah bersifat hubungan kausal. Menurut Sugiyono (2012:18), penelitian kuantitatif dalam melihat hubungan variabel terhadap obyek yang diteliti lebih bersifat sebab dan akibat (kausal), sehingga dalam penelitiannya ada variabel independen dan dependen. Dari variabel tersebut selanjutnya dicari seberapa besar pengaruh variabel independen terhadap variabel dependen.

\subsection{Populasi dan Sampel Populasi}

Menurut Sugiyono (2012:115), populasi adalah wilayah generalisasi yang terdiri atas obyek/subyek yang mempunyai kualitas dan karakteristik tertentu yang ditetapkan oleh peneliti untuk dipelajari dan kemudian ditarik kesimpulannya.

Populasi yang digunakan dalam penelitian ini adalah semua Perusahaan
Consumer Goods yang terdaftar di Bursa Efek Indonesia periode 2011-2017 sebanyak 37 perusahaan.

\section{Sampel}

Menurut Sugiyono (2012:116), Sampel adalah bagian dari jumlah dan karakteristik yang dimiliki oleh populasi tersebut.

Sampel yang digunakan dalam penelitian ini ditentukan dengan menggunakan teknik purposive sampling. Teknik purposive sampling dilakukan dengan mengambil sampel dari populasi berdasarkan kriteria tertentu. Penggunaan metode ini bertujuan untuk mendapatkan sampel yang konsisten dan representatif, sesuai dengan kriteria-kriteria yang digunakan. Adapun kriteria yang digunakan untuk memilih sampel adalah sebagai berikut:

1. Perusahaan Consumer Goods yang terdaftar di Bursa Efek Indonesia Periode 2011-2017.

2. Perusahaan Consumer Goods yang mempublikasikan laporan keuangan selama Periode 2011-2017.

3. Perusahaan Consumer Goods yang membagikan dividen dan memiliki investasi selama Periode 2011-2017.

Sampel penelitian sebanyak 6 Perusahaan Consumer Goods yang terdaftar di Bursa Efek Indonesia periode 2011-2017. Sampel perusahaan sebanyak 6 perusahaan memiliki kriteria tertentu diuraikan pada tabel II.1 sebagai berikut:

\section{Tabel 2.1. Sampel Penelitian}

\begin{tabular}{|c|l|c|}
\hline No. & \multicolumn{1}{|c|}{ Kriteria } & $\begin{array}{c}\text { Jumlah } \\
\text { Sampel }\end{array}$ \\
\hline 1. & $\begin{array}{l}\text { Perusahaan Consumer Goods } \\
\text { yang terdaftar di Bursa Efek } \\
\text { Indonesia Periode 2011-2017 }\end{array}$ & 37 \\
\hline 2. & $\begin{array}{l}\text { Perusahaan Consumer Goods } \\
\text { yang tidak menyajikan } \\
\text { laporan keuangan Periode } \\
\text { 2011-2017 }\end{array}$ & (3) \\
\hline
\end{tabular}




\begin{tabular}{|l|l|c|}
\hline $3 . \quad \begin{array}{l}\text { Perusahaan Perusahaan } \\
\text { Consumer Goods yang tidak } \\
\text { membagi dividen dan tidak } \\
\text { memiliki invesasi Periode } \\
2011-2017\end{array}$ & (28) \\
\hline $\begin{array}{c}\text { Total Perusahaan yang memenuhi } \\
\text { kriteria sampel }\end{array}$ & 6 \\
\hline $\begin{array}{c}\text { Jumlah sampel penelitian }(6 \times 7 \\
\text { tahun })\end{array}$ & 42 \\
\hline
\end{tabular}

\subsection{Jenis dan Sumber Data}

Penelitian yang akan dilakukan ini merupakan jenis penelitian kuantitatif, dimana data yang dikumpulkan dalam bentuk angka-angka yang merupakan data sekunder yaitu laporan keuangan perusahaan Consumer Goods yang terdaftar di Bursa Efek Indonesia Periode 20112017. Menurut Sugiyono (2012:18), penelitian kuantitatif dalam melihat hubungan variabel terhadap obyek yang diteliti lebih bersifat sebab dan akibat/kausal, sehingga dalam penelitiannya ada variabel independen dan dependen. Dari variabel tersebut selanjutnya dicari seberapa besar pengaruh variabel independen terhadap variabel dependen.

\subsection{Identifikasi dan Definisi Operasional Variabel Penelitian}

Definisi operasional variabel penelitian dapat di sajikan pada tabel II.2 sebagai berikut:

Tabel II.2

Identifikasi dan Defenisi Operasional Variabel Penelitian

\begin{tabular}{|c|c|c|c|}
\hline Variabel & Definisi & Indikator & $\begin{array}{l}\text { Skala } \\
\text { Ukur }\end{array}$ \\
\hline $\begin{array}{l}\text { Rasio lancar } \\
\qquad\left(\mathrm{X}_{1}\right)\end{array}$ & $\begin{array}{l}\text { Rasio lancar (current ratio) adalah ukuran } \\
\text { yang umum digunakan atas solvensi jangka } \\
\text { pendek, kemampuan suatu perusahaan } \\
\text { memenuhi kebutuhan utang ketika jatuh } \\
\text { tempo. } \\
\text { Sumber : Fahmi (2012 : 66) }\end{array}$ & $\begin{array}{l}\text { Current Ratio }= \\
\text { Aktiva Lancar (Current Assets) } \\
\text { Hutang Lancar (Current Liabilities) } \\
\text { Sumber : Kasmir (2009:135) }\end{array}$ & Rasio \\
\hline $\begin{array}{l}\text { Debt to Asset } \\
\text { Ratio } \\
\left(\mathrm{X}_{2}\right)\end{array}$ & $\begin{array}{l}\text { Debt ratio merupakan rasio utang yang } \\
\text { digunakan untuk mengukur perbandingan } \\
\text { antara total utang dengan aktiva.. } \\
\text { Sumber : Kasmir (2009:156) }\end{array}$ & $\begin{array}{l}\text { Debt to Total Assets = } \\
\frac{\text { Total Debt }}{\text { Total assets }} \\
\text { Sumber : Kasmir (2009:156) }\end{array}$ & Rasio \\
\hline $\begin{array}{l}\text { Return On } \\
\text { Invesment } \\
\quad\left(\mathrm{X}_{3}\right)\end{array}$ & $\begin{array}{l}\text { Return on Investment (ROI) atau return on } \\
\text { total asset merupakan rasio yang } \\
\text { menunjukkan hasil (return) atas jumlah } \\
\text { aktiva yang digunakan dalam perusahaan. } \\
\text { Sumber : Kasmir (2009:201) }\end{array}$ & $\begin{array}{l}\text { Return on investment (ROI) }= \\
\frac{\text { EBIT }}{\text { Total Investasi }} \times 100 \% \\
\text { Sumber : Soemohadiwidjojo } \\
(\mathbf{2 0 1 7 : 5 0 )}\end{array}$ & Rasio \\
\hline $\begin{array}{l}\text { Dividend } \\
\text { Payout Ratio } \\
\text { (Y) }\end{array}$ & $\begin{array}{l}\text { Rasio pembayaran dividen (dividend } \\
\text { payout ratio-DPR) atau sering disebut } \\
\text { payout ratio merupakan rasio yang } \\
\text { mengukur perbandingan dividen terhadap } \\
\text { laba perusahaan.. } \\
\text { Sumber : Darmadji dan Fakhruddin } \\
(\mathbf{2 0 1 2 : 1 5 9 )}\end{array}$ & $\begin{array}{l}\text { DPR }=\frac{\text { Dividen Per Saham }}{\text { EPS }} \\
\text { Sumber : Darmadji dan } \\
\text { Fakhruddin (2012:159) }\end{array}$ & Rasio \\
\hline
\end{tabular}

Sumber : Data sekunder 


\section{HASIL PENELITIAN DAN PEMBAHASAN}

\section{Hasil Penelitian}

Data penelitian yang dideskripsikan dapat dilihat dari jumlah data, nilai minimum, nilai maksimum, nilai rata-rata (mean), dan standar deviasi.Berdasarkan data statistik dari seluruh data variabel yang digunakan dalam penelitian ini adalah :

Tabel 3.1

\begin{tabular}{|c|c|c|c|c|c|}
\hline & \multirow[b]{2}{*}{$\mathrm{N}$} & \multicolumn{3}{|c|}{ Descriptive Statistics } & \multirow[b]{2}{*}{$\begin{array}{c}\text { Std. } \\
\text { Deviation }\end{array}$} \\
\hline & & $\begin{array}{c}\text { Minimu } \\
\mathrm{m}\end{array}$ & $\begin{array}{c}\text { Maximu } \\
\mathrm{m}\end{array}$ & Mean & \\
\hline \multirow[t]{2}{*}{ CR } & 4 & 1,50 & 6,57 & 2,7236 & 1,11651 \\
\hline & 2 & & & & \\
\hline DAR & 4 & , 16 & ,58 & -3498, & ,11657 \\
\hline \multirow[t]{2}{*}{ ROI } & 4 & 38,95 & 40129,51 & 6039,032 & 9851,5552 \\
\hline & 2 & & & 9 & 7 \\
\hline \multirow[t]{2}{*}{ DPR } & 4 & , 00 & ,77 & ,3293 & 22218 \\
\hline & 2 & & & & \\
\hline Valid N & 4 & & & & \\
\hline (listwise & 2 & & & & \\
\hline
\end{tabular}

\section{Sumber : Data Diolah (2019)}

\section{Uji Asumsi Klasik}

\section{Uji Normalitas}

Uji normalitas digunakan untuk menguji apakah data residual sudah berdistribusi secara normal atau tidak normal. Penelitian ini menggunakan uji normalitas dengan menggunakan statistik non parametrik Kolmogorov Smirnov Test sehingga pedoman pengambilan keputusan data mendekati atau merupakan distribusi normal dengan syarat sebagai berikut:

a. Jika nilai signifikan > 0,05 maka distribusi normal,

b. Jika nilai signifikan $<0,05$ maka distribusi tidak normal.

Hasil dari uji normalitas dengan menggunakan statistic Kolmogorov Smirnov Test :
Tabel III.2. One-Sample KolmogorovSmirnov Test

One-Sample Kolmogorov-Smirnov Test

Unstandardized Residual

\begin{tabular}{llr}
\hline $\mathrm{N}$ & & 42 \\
\hline Normal & Mean &, 0000000 \\
\cline { 2 - 3 } Parameters $^{\mathrm{a}, \mathrm{b}}$ & Std. &, 16552467 \\
& Deviation &, 113 \\
\hline Most Extreme & Absolute &, 113 \\
\cline { 2 - 3 } Differences & Positive &,- 081 \\
\cline { 2 - 3 } & Negative &, 113 \\
\hline Test Statistic & &, $200^{\text {c,d }}$ \\
\hline Asymp. Sig. (2-tailed) &
\end{tabular}

a. Test distribution is Normal.

b. Calculated from data.

c. Lilliefors Significance Correction.

$\mathrm{d}$. This is a lower bound of the true significance.

Sumber : Hasil Pengolahan Data, 2019

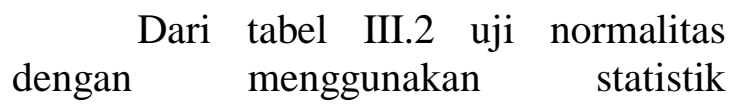
Kolmogorov-Smirnov di atas, dapat diketahui bahwa variabel rasio lancar, debt to total aset, return on investment dan dividen payout ratio telah memenuhi syarat distribusi normal karena nilai sig 0,200> 0,05 sehingga data tersebut normal.

\section{Uji Multikolinieritas}

Uji multikolinearitas digunakan untuk menguji apakah model regresi ditemukan adanya korelasi antar variabel independen dengan variabel dependen. Cara pengambilan keputusan yaitu nilai $\mathrm{VIF} \leq 10$ dan nilai tolerance $\geq 0,10$ maka regresi bebas multikolinearitas. VIF adalah satu dibanding tolerance.

Hasil pengujian multikolinearitas penelitian ini dapat dilihat pada tabel III.3 berikut ini:

Tabel 3.3. Uji Multikolinieritas

\begin{tabular}{|c|c|c|c|}
\hline \multicolumn{2}{|c|}{ Model } & \multicolumn{2}{|c|}{ Collinearity Statistics } \\
\hline 1 & (Constant) & & \\
\hline & $\mathrm{CR}$ & ,255 & 3,923 \\
\hline & DAR & 256 & 3,913 \\
\hline & ROI & -986 & 1,014 \\
\hline
\end{tabular}


Berdasarkan tabel III.3 diatas menunjukkan nilai tolerance variabel rasio lancar, debt to total aset, return on investment lebih besar dari 0,10 dapat disimpulkan bahwa tidak terjadi multikolinearitas. Nilai VIF yang diperoleh untuk variabel rasio lancar, debt to total aset, return on investment lebih kecil 10. Jadi dapat disimpulkan bahwa tidak terjadi multikolinearitas antar variabel independen dalam model regresi tersebut.

\section{Uji Autokorelasi}

Uji autokorelasi digunakan untuk menguji apakah dalam sebuah model regresi linear ada korelasi antara kesalahan pengganggu pada periode $t$ dengan kesalahan pengganggu pada periode $t-1$ (periode sebelumnya). Salah satu ukuran dalam menentukan ada tidaknya masalah autokorelasi dengan uji Durbin-Watson (DW-test). Berikut hasil uji autokorelasi dengan uji Durbin-Watson :

Tabel 3.4 Uji Autokorelasi

\begin{tabular}{|c|c|c|c|c|c|}
\hline \multicolumn{6}{|c|}{ Model Summary $^{\text {b }}$} \\
\hline Model & $\mathrm{R}$ & $\begin{array}{c}\mathrm{R} \\
\text { Square }\end{array}$ & $\begin{array}{l}\text { Adjusted } \\
\text { R Square }\end{array}$ & $\begin{array}{l}\text { Std. Error } \\
\text { of the } \\
\text { Estimate }\end{array}$ & $\begin{array}{l}\text { Durbin- } \\
\text { Watson }\end{array}$ \\
\hline 1 & $667^{\mathrm{a}}$ & ,445 & ,401 & ,17193 & 1,637 \\
\hline
\end{tabular}

Berdasarkan tabel III.4 diatas menunjukkan bahwa nilai DW yang diperoleh adalah sebesar 1,637. Cara pengukuran uji autokorelasi adalah du < dw $<4-$ du. Nilai dl dan du dalam penelitian ini dengan menggunakan jumlah 3 variabel dan sampel penelitian sebanyak 42 maka nilai $\mathrm{dl}=1,3573$ dan nilai $\mathrm{du}=$ 1,6617. Hasil pengukurannya adalah du < $\mathrm{dw}<4-$ du maka $1,6617<1,637<(4-$ 1,6617) sehingga maka $1,6617>1,637<$ 2,3383 sehingga disimpulkan terjadi autokorelasi dalam penelitian ini.
Pengujian autokorelasi dengan menggunakan run-test dapat disajikan sebagai berikut :

\section{Tabel III.5}

Runs Test

Unstandardized Residual

\begin{tabular}{lr}
\hline Test Value $^{\mathrm{a}}$ & Unstandardized Residual \\
\hline Cases $<$ Test Value &, 00030 \\
\hline Cases $>=$ Test Value & 21 \\
\hline Total Cases & 21 \\
\hline Number of Runs & 42 \\
\hline Z & 16 \\
\hline Asymp. Sig. (2-tailed) & $-1,718$ \\
\hline a. Median &, 086 \\
\hline
\end{tabular}

a. Median

Dari tabel III.5 di atas menunjukkan asymp sig. pada output runs test sebesar 0,086 >0,05, maka data tidak mengalami/mengandung autokorelasi.

\section{Uji Heteroskedastisitas}

Uji Heteroskedastisitas berguna untuk menguji apakah dalam model regresi terjadi ketidaksamaan varian dari residual satu pengamatan ke pengamatan yang lain. Cara pengambilan keputusan adalah dengan melihat grafik Scatterplot sebagai berikut

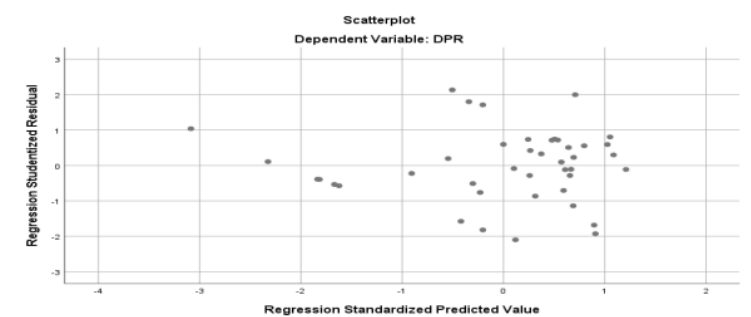

Gambar 3.1: Uji Heteroskedastisitas Sumber : Data Diolah (2019)

Dari Gambar III.1 menunjukkan bahwa data tersebar secara acak dan tidak membentuk suatu pola tertentu. Data tersebar diatas garis 0 yang menunjukkan tidak terjadi heteroskedastisitas. 


\begin{tabular}{|c|c|c|c|c|c|}
\hline \multicolumn{6}{|c|}{$\begin{array}{l}\text { Tabel 3.6. Hasil Persamaan Regresi } \\
\text { Linear Berganda } \\
\text { Coefficients }^{\mathrm{a}}\end{array}$} \\
\hline \multirow[b]{2}{*}{ Model } & $\begin{array}{r}\text { Unstand } \\
\text { Coeffi }\end{array}$ & $\begin{array}{l}\text { rdized } \\
\text { ients }\end{array}$ & $\begin{array}{c}\text { Standardized } \\
\text { Coefficients }\end{array}$ & \multirow[b]{2}{*}{$\mathrm{t}$} & \multirow[b]{2}{*}{ Sig. } \\
\hline & B & $\begin{array}{l}\text { Std. } \\
\text { Error }\end{array}$ & & & \\
\hline 1 (Constant) & 1,670 & ,281 & & 5,943 &, 000 \\
\hline CR &,- 224 & , 048 & $-1,128$ & $4,712^{-}$ & ,000 \\
\hline DAR & $-1,943$ & ,456 & $-1,019$ & 4,264 & ,000 \\
\hline ROI & $\begin{array}{r}8,324 \mathrm{E}- \\
6\end{array}$ & , 000 &,- 369 & 3,033 & ,004 \\
\hline
\end{tabular}

Sumber : Data Olahan SPSS

Berdasarkan Tabel III.6 pada kolom Unstandardized Coefficients bagian B diperoleh model permasaan regresi linear berganda yaitu:

$\mathrm{DPR}=1,670-0,224 \mathrm{CR}-1,943 \mathrm{DAR}-$ 8,324 ROI

1. Nilai a sebesar 1,670 artinya jika variabel rasio lancar, debt to total aset, return on investment dianggap konstan, maka dividen payout ratio adalah sebesar 1,670.

2. Nilai koefisien rasio lancar $\left(\mathrm{X}_{1}\right)$ adalah $-0,224$. Ini menunjukkan bahwa setiap peningkatan rasio lancar satu kali maka dividen payout ratio akan mengalami penurunan sebesar 0,224.

3. Nilai koefisien debt to total aset $\left(\mathrm{X}_{2}\right)$ sebesar -1,943. Ini menunjukkan bahwa setiap peningkatan debt to total aset satu kali maka dividen payout ratio akan mengalami penurunan sebesar 1,943 .

4. Nilai koefisien return on investment $\left(\mathrm{X}_{3}\right)$ sebesar 8,324. Ini menunjukkan bahwa setiap peningkatan return on investment satu kali maka dividen payout ratio akan mengalami peningkatan sebesar 8,324.
Tabel. 3.7. Koefisien Determinasi Model Summary ${ }^{b}$

\begin{tabular}{ll|r|r|r} 
& & & & \multicolumn{1}{c}{$\begin{array}{c}\text { Std. } \\
\text { Error of } \\
\text { the }\end{array}$} \\
Model & $\mathrm{R}$ & $\mathrm{R}$ & Square & Adjusted \\
R Square & Estimate \\
\hline 1 &, $667^{\mathrm{a}}$ &, 445 &, 401 &, 17193 \\
\hline
\end{tabular}

a. Predictors: (Constant), ROI, DAR, CR

b. Dependent Variable: DPR

Sumber: data olahan SPSS

Berdasarkan tabel III.7 di atas diperoleh nilai adjusted $R$ Square $\left(\mathrm{R}^{2}\right)$ koefisien determinasi sebesar 0,401 atau sama dengan $40,1 \%$ dipengaruhi oleh variabel independen terhadap variabel dependen sedangkan sisanya $59,9 \%$ dipengaruhi variabel lain seperti seperti kesempatan investasi, earning per share dan tingkat pertumbuhan perusahaan.

Tabel. III.8: Hasil Uji Statistik F ANOVA $^{\mathrm{a}}$

\begin{tabular}{|c|c|c|c|c|c|}
\hline \multicolumn{6}{|c|}{ ANOVA $^{\mathrm{a}}$} \\
\hline Model & $\begin{array}{l}\text { Sum } \\
\text { of } \\
\text { Squar } \\
\text { es }\end{array}$ & $\begin{array}{l}\mathrm{d} \\
\mathrm{f}\end{array}$ & $\begin{array}{l}\text { Mean } \\
\text { Squar } \\
\text { e }\end{array}$ & $\mathrm{F}$ & Sig. \\
\hline $\begin{array}{l}1 \text { Regressi } \\
\text { on }\end{array}$ & ,901 & 3 & ,300 & $\begin{array}{r}10,15 \\
4\end{array}$ & $\begin{array}{r}, 000 \\
\mathrm{~b}\end{array}$ \\
\hline Residual & 1,123 & $\begin{array}{l}3 \\
8\end{array}$ & ,030 & & \\
\hline Total & 2,024 & $\begin{array}{l}4 \\
1\end{array}$ & & & \\
\hline
\end{tabular}

a. Dependent Variable: DPR

b. Predictors: (Constant), ROI, DAR, CR

Dari tabel III.8 bisa dilihat hasil $F_{\text {hitung }}$ adalah sebesar 10,154 dengan nilai signifikan 0,000 , sedangkan $\mathrm{F}_{\text {tabel }}(42-4)=$ 38 adalah sebesar 2,85 maka kesimpulannya adalah $\mathrm{F}_{\text {hitung }}>\mathrm{F}_{\text {tabel }}$ yaitu $10,154>2,85$ sehingga keputusannya adalah Ho ditolak dan Ha diterima, artinya variabel rasio lancar, debt to total aset, return on investment berpengaruh dan signifikan terhadap dividen payout ratio di Perusahaan Consumer Goods yang 
terdaftar di Bursa Efek Indonesia Periode 2011-2017.

\section{Tabel 3.9. Hasil Uji Statistik t}

\begin{tabular}{|c|c|c|c|c|c|}
\hline \multicolumn{6}{|c|}{ Coefficients $^{a}$} \\
\hline \multirow[b]{2}{*}{ Model } & $\begin{array}{r}\text { Unstand } \\
\text { Coeffi }\end{array}$ & $\begin{array}{l}\text { dized } \\
\text { ents }\end{array}$ & $\begin{array}{l}\text { Standardized } \\
\text { Coefficients }\end{array}$ & \multirow[b]{2}{*}{$\mathrm{t}$} & \multirow[b]{2}{*}{ Sig. } \\
\hline & B & $\begin{array}{l}\text { Std. } \\
\text { Error }\end{array}$ & Beta & & \\
\hline $1 \quad$ (Constant) & 1,670 & ,281 & & 5,943 &, 000 \\
\hline CR &,- 224 & ,048 & $-1,128$ & $4,712^{-}$ &, 000 \\
\hline DAR & $-1,943$ & ,456 & $-1,019$ & 4,264 & ,000 \\
\hline ROI & $\begin{array}{r}8,324 \mathrm{E}- \\
6\end{array}$ & ,000 &,- 369 & 3,033 & ,004 \\
\hline
\end{tabular}

a. Dependent Variable: DPR

Sumber : Data Olahan SPSS

1. Variabel rasio lancar mempunyai nilai

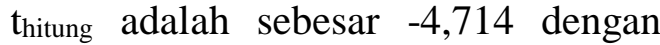
nilai signifikan $0,000<0,05$, sedangkan nilai $t_{\text {tabel }}(42-4)=38$ adalah sebesar 2,024 sehingga kesimpulannya adalah $-t_{\text {hitung }}>\quad-t_{\text {tabel }}$ yaitu $-4,714<-2,024$ maka keputusannya adalah Ho diterima dan $\mathrm{H}_{\mathrm{a}}$ ditolak, artinya variabel rasio lancar berpengaruh dan signifikan terhadap dividen payout ratio di Perusahaan Consumer Goods yang terdaftar di Bursa Efek Indonesia Periode 2011-2017.

2. Variabel Debt to total aset mempunyai nilai $t_{\text {hitung }}-4,264$ dengan nilai signifikan $0,000<0,05$, sedangkan $t_{\text {tabel }}$ adalah sebesar 2,024 maka kesimpulannya adalah $-\mathrm{t}_{\text {hitung }}<-\mathrm{t}_{\text {tabel }}$ yaitu $\quad-4,264<-2,024 \quad$ sehingga keputusannya adalah Ho diterima dan $\mathrm{H}_{\mathrm{a}}$ ditolak, artinya variabel debt to total aset berpengaruh dan signifikan terhadap dividen payout ratio di Perusahaan Consumer Goods yang terdaftar di Bursa Efek Indonesia Periode 2011-2017.

3. Variabel return on investment mempunyai nilai $t_{\text {hitung }}-3,033$ dengan nilai signifikan $0,004<0,05$, sedangkan $t_{\text {tabel }}$ adalah sebesar 2,024 maka kesimpulannya adalah $-\mathrm{t}_{\text {hitung }}<-\mathrm{t}_{\text {tabel }}$ yaitu $\quad-3,033<-2,024 \quad$ sehingga keputusannya adalah Ho diterima dan $\mathrm{H}_{\mathrm{a}}$ ditolak, artinya variabel return on investment berpengaruh dan signifikan terhadap dividen payout ratio di Perusahaan Consumer Goods yang terdaftar di Bursa Efek Indonesia Periode 2011-2017.

\section{PEMBAHASAN}

Pengaruh Rasio Lancar Terhadap Dividen Payout Ratio

Rasio Lancar berpengaruh dan signifikan terhadap dividen payout ratio di Perusahaan Consumer Goods yang terdaftar di Bursa Efek Indonesia Periode 2011-2017.

Hasil penelitian ini sesuai dengan teori Rodoni dan Ali (2014:117) posisi likuiditas, yaitu apabila laba yang ditahan telah diinvestasikan dalam bentuk aktiva tetap dan bukan disimpan dalam bentuk uang tunai, maka posisi likuiditas perusahaan yang rendah dan terdapat kemungkinan perusahaan tidak mampu lagi membayarkan dividennya.

Hasil penelitian ini sejalan dengan penelitian yang dilakukan Diantini dan Badjra (2016) yang menyatakan, Current ratio berpengaruh positif dan signifikan kebijakan dividen.

\section{Pengaruh Debt to Asset Ratio Terhadap Dividen Payout Ratio}

Debt to total aset berpengaruh dan signifikan terhadap dividen payout ratio di Perusahaan Consumer Goods yang terdaftar di Bursa Efek Indonesia Periode 2011-2017.

Hasil penelitian ini sesuai dengan Hery (2013:37) semakin besar proporsi utang yang digunakan dalam struktur modal, maka akan semakin besar jumlah 
kewajiban perusahaan kepada kreditor. Peningkatan saldo utang akan mempengaruhi besar kecilnya laba yang tersedia, termasuk dividen yang akan diterima, karena pembayaran kewajiban kepada kreditor akan menjadi lebih diprioritaskan dari pada pembayaran dividen. Jika beban utang semakin tinggi, maka kemampuan perusahaan untuk membagi dividen akan semakin rendah.

Hasil penelitian ini sejalan dengan penelitian Mawarni dan Ratnadi (2014) yang menyatakan, leverage berpengaruh negatif pada kebijakan dividen.

\section{Pengaruh Return On Invesment Terhadap Dividen Payout Ratio}

Return on investment berpengaruh dan signifikan terhadap dividen payout ratio di Perusahaan Consumer Goods yang terdaftar di Bursa Efek Indonesia Periode 2011-2017.

Hasil penelitian ini sesuai dengan teori Sjahrial (2008:306) besarnya dividen yang dibagikan akan tergantung pada laba yang diperoleh preusahaan. Peruahaan hanya bisa meningkatkan pembagian dividen kalau laba meningkat. Maksimum jumlah dividen yang dibagikan akan sama dengan laba yang diperoleh.

Hasil penelitian ini sejalan dengan penelitian yang dilakukan Rachmat, Rikumahu dan Iradianty (2016) yang menyatakan, secara parsial ROI tidak mempunyai pengaruh signifikan terhadap DPR.

\section{KESIMPULAN DAN SARAN Kesimpulan}

Berdasarkan pada hasil penelitian, maka dapat ditarik beberapa kesimpulan sebagai berikut:

1. Rasio Lancar berpengaruh dan signifikan terhadap dividen payout ratio di Perusahaan Consumer Goods yang terdaftar di Bursa Efek Indonesia Periode 2011-2017.

2. Debt to total aset berpengaruh dan signifikan terhadap dividen payout ratio di Perusahaan Consumer Goods yang terdaftar di Bursa Efek Indonesia Periode 2011-2017.

3. Return on investment berpengaruh dan signifikan terhadap dividen payout ratio di Perusahaan Consumer Goods yang terdaftar di Bursa Efek Indonesia Periode 2011-2017.

4. Rasio lancar, debt to total aset, return on investment berpengaruh dan signifikan terhadap dividen payout ratio di Perusahaan Consumer Goods yang terdaftar di Bursa Efek Indonesia Periode 2011-2017.

\section{Saran}

Berdasarkan hasil penelitian yang telah peneliti kemukakan, saran-saran yang dapat peneliti berikan adalah sebagai berikut:

1. Pihak manajemen perusahaan harus memperhatikan return on investment yang mempengaruhi dividen payout ratio karena para investor lebih tertarik pada perusahaan yang memiliki laba tinggi dibandingkan perusahaan memiliki laba rendah.

2. Bagi para investor hasil penelitian ini dapat dijadikan sebagai bahan pertimbangan sebelum melakukan investasi di perusahaan Consumer Goods yang terdaftar di Bursa Efek Indonesia.

3. Bagi Universitas Prima Indonesia sebaiknya hasil penelitian dapat menjadi referensi bahan kepustakaan di bidang manajemen keuangan di kampus Universitas Prima Indonesia.

\section{DAFTAR PUSTAKA}


Gumanti, Tatang Ary. 2013. Kebijakan Deviden. Jakarta : Penerbit UPP STIM YKPN.

Hery. 2013. Rahasia Pembagian Dividen \& Tata Kelola Perusahaan. Yogyakarta : Penerbit Gava Media.

Nidar, Sulaeman Rahman. 2016. Manajemen Keuangan

Perusahaan Modern. Cetakan Pertama. Bandung : Penerbit Pustaka Reka Cipta.

Rodoni, Ahmad \& Ali, Herni. 2014. Manajemen Keuangan Modern. Jakarta : Penerbit Mitra Wacana Media.

Sjahrial, Dermawan. 2013. Manajemen Keuangan Lanjutan. Edisi Pertama. Jakarta : Mitra Wacana Media.

Soewadji, Jusuf. 2012. Pengantar Metodologi Penelitian. Jakarta : Penerbit Mitra Wacana Media

Sugiyono. 2012. Metode Penelitian Bisnis. Cetakan Keenam Belas. Bandung: Penerbit Alfabeta. 